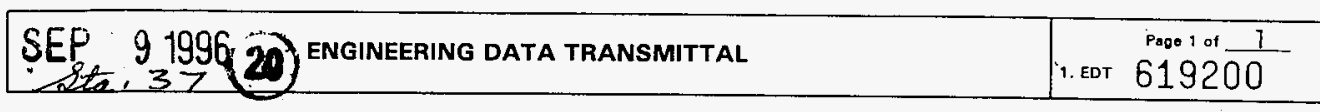

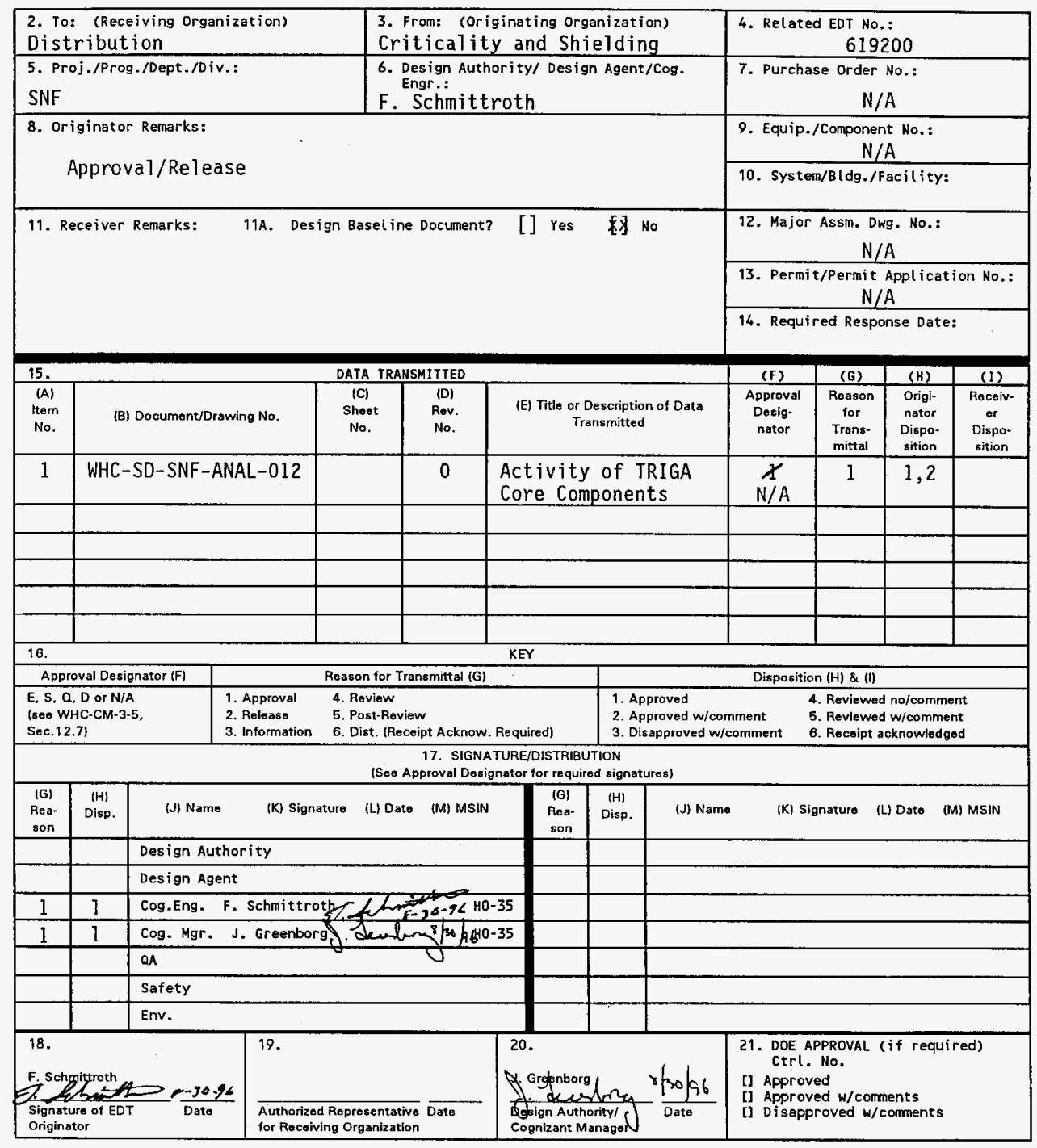




\title{
Activity of TRIGA Core Components
}

\author{
F. Schmittroth \\ Westinghouse Hanford Company, Richland, WA 99352 \\ U.S. Department of Energy Contract DE-ACO6-87RL10930 \\ $\begin{array}{lll}\text { EDT/ECN: } & 619200 & \text { UC: } 510 \\ \text { Org Code: } & 8 M 730 & \text { Charge Code: } \\ \text { B\&R Code: } & \text { EW31350406 } & \text { Total Pages: }\end{array}$ \\ Key Words: TRIGA Activity \\ Abstract: The activity of TRIGA core components was estimated.
}

TRADEMARK DISCLAIMER. Reference herein to any specific commercial product, process, or service by trade name, trademark, manufacturer, or otherwise, does not necessarily constitute or imply its endorsement, recommendation, or favoring by the United States Government or any agency thereof or its contractors or subcontractors.

Printed in the United States of America. To obtain copies of this document, contact: WHC/BCS Document Control Services, P.O. Box 1970, Mailstop H6-08, Richland WA 99352, Phone (509) 372-2420; Fax (509) 376-4989.

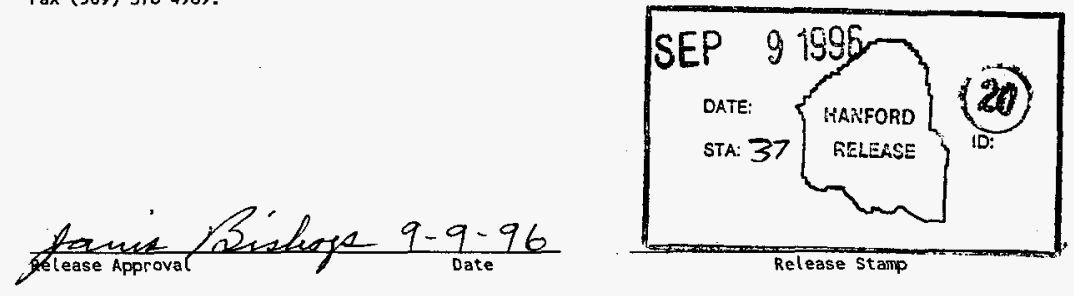

\section{Approved for Public Release}


WHC-SD-SNF-ANAL-012, ReV. 0

Page 1 of 3

\section{ACTIVITY OF TRIGA CORE COMPONENTS}

\subsection{INTRODUCTION}

Activities for two groups of TRIGA core components are estimated: three stainless steel clad boron-carbide control rods and eleven aluminum clad graphite reflectors. The maximum measured contact dose rates are $50 \mathrm{mrem} / \mathrm{hr}$ for the control rods and $14 \mathrm{mrem} / \mathrm{hr}$ for the reflectors.

None of the materials in either group of elements are expected to activate significantly. The likely source of the measured dose rate is ${ }^{60} \mathrm{Co}$ activity. Cobalt 60 can occur from activation of trace cobalt impurities in stainless steel. Activation of copper, a common aluminum alloy, can also produce ${ }^{60} \mathrm{Co}$. Abrasion and contamination from other components is another possible source.

\subsection{CALCULATIONS}

A rough estimate of the magnitude of cobalt activity that gives the measured dose rate was found as follows.

The unattenuated photon flux (the greater than 1 MeV photons from ${ }^{60}$ Co are highly penetrating) from a cylindrical surface source is given by (Jaeger 1968)

$$
\phi=\frac{S_{A} R}{2(a+R)}\left[F\left(\phi_{1}, k\right)+F\left(\phi_{2}, k\right)\right]
$$

where $S_{A}$ is the surface source density, $R$ is the radius of the cylinder, and $a$ is the distance from the cylinder centerline. The function $F$ and its arguments are defined in the reference which gives a value near 0.3 for points near the surface of the cylinder (see Figure 6.8,-5).

This result can be used to relate the photon flux $\Phi$ to an equivalent flux $\Phi_{0}$ a distance $x$ from a point source (equivalent in the sense of having a common total source strength):

$$
\phi=\left(\frac{0.6}{a+R)}\right) \frac{1}{h}\left(x^{2} \phi_{0}\right)
$$

where $\mathrm{h}$ is the height of the cylinder. 


$$
\text { WHC-SD-SNF-ANAL-012, Rev. } 0
$$

The same equation relates the measured dose rate $D_{m}$ to an equivalent point source dose rate $D_{0}$. In turn, the dose rate from a point source is related to the source activity, $A$, by the specific gamma-ray constant, $\Gamma$ :

$$
x^{2} D_{0}=\Gamma A
$$

Combining these results gives the desired activity as

$$
A=\frac{h(a+R)}{0.6 \Gamma} D_{\mathrm{m}}
$$

For dimensions typical of a TRIGA component ( $h=50 \mathrm{~cm}$, and $a=R=1.8 \mathrm{~cm}$ ), the factors that relate the point and cylindrical geometries give a factor of 300 . Together with a value of $\Gamma$ for ${ }^{60} \mathrm{Co}$ (Jaeger 1968 ) of $13.2\left(\mathrm{R} \mathrm{cm}^{2}\right) /(\mathrm{h} \mathrm{mCi})$ the following table was constructed:

$\begin{array}{lrccc}\text { Component } & \text { N } & \text { mrem/hr } & \begin{array}{c}-- \text { Activity, mCi } \\ \text { single element }\end{array} & \text { total } \\ \text { Control rods } & 3 & 50 & 1.15 & 3.4 \\ \text { Reflectors } & 11 & 14 & 0.32 & 3.5\end{array}$

\subsection{REFERENCES}

R. G. Jaeger, et.al., 1968, Engineering Compendium on Radiation Shielding, Springer-Verlag, New York, NY. 


\section{CHECKLIST FOR INDEPENDENT TECHNICAL. REVIEW}

DOCUMENT REVIEWED Activity of TRIGA Core Components

\section{AUTHOR(s) F.A. Schmittroth}

I. Method(s) of Review

( ) Input data checked for accuracy

$(X)$ Independent calculation performed

( $X)$ Hand calculation

() Alternate computer code:

( ) Comparison to experiment or previous results

() Alternate method (define)

I1. Checklist (either check or enter NA if not applied)

(X) Task completely defined

$(X)$ Activity consistent with task specification

(X) Necessary assumptions explicitly stated and supported

( $X$ ) Resources properly identified and referenced

(X) Resource documentation appropriate for this application

(X) Input data explicitly stated

( $X$ ) Input data verified to be consistent with original source

$(X)$ Geometric model adequate representation of actual geometry

(X) Material properties appropriate and reasonable

( $X$ ) Mathematical derivations checked including dimensional consistency

( $X$ ) Hand calculations checked for errors

(X) Assumptions explicitly stated and justified

(NA) Computer software appropriate for task and used within range of validity

(NA) Use of resource outside range of established validity is justified

(NA) Software runstreams correct and consistent with results

(NA) Software output consistent with input

( $X$ ) Results consistent with applicable previous experimental or analytical findings

( $X$ ) Results and conclusions address all points and are consistent with task requirements and/or established limits or criteria

( $X$ ) Conclusions consistent with analytical results and established limits

(X) Uncertainty assesment appropriate and reasonable

(NA) Other (define)

III. Comments:

IV.

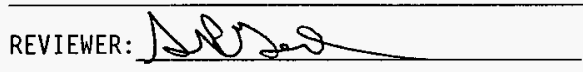

DATE: $30 A_{\text {vey }} 96$ 


\begin{tabular}{|c|c|c|c|c|c|}
\hline \multicolumn{6}{|c|}{ DISTRIBUTION SHEET } \\
\hline \multirow{2}{*}{$\begin{array}{l}\text { To } \\
\text { Distribution }\end{array}$} & \multirow{2}{*}{\multicolumn{3}{|c|}{$\begin{array}{l}\text { From } \\
\text { Criticality and Shielding }\end{array}$}} & \multicolumn{2}{|l|}{ Page 1 of 1} \\
\hline & & & & \multicolumn{2}{|c|}{ Date August 29, 1996} \\
\hline \multirow{2}{*}{\multicolumn{4}{|c|}{$\begin{array}{l}\text { Project Title/Work Order } \\
\text { Activity of TRIGA Core Components }\end{array}$}} & \multicolumn{2}{|c|}{ EDT No. 619200} \\
\hline & & & & \multicolumn{2}{|c|}{ ECN No. N/A } \\
\hline Name & MSIN & $\begin{array}{l}\text { Text } \\
\text { With All } \\
\text { Attach. }\end{array}$ & Text Only & $\begin{array}{l}\text { Attach./ } \\
\text { Appendix } \\
\text { Only }\end{array}$ & $\begin{array}{c}\text { EDT/ECN } \\
\text { Only }\end{array}$ \\
\hline J. 0. Dittmer & $\mathrm{N} 2-02$ & $x$ & & & \\
\hline J. Greenborg & $\mathrm{H} 0-35$ & $x$ & & & \\
\hline A. L. Ramble & $A 3-38$ & $x$ & & & \\
\hline F. A. Schmittroth & HO-35 & $x$ & & & \\
\hline Central Files (2) & $A 3-88$ & $x$ & & & \\
\hline
\end{tabular}

